\title{
MEDIA PEMBELAJARAN APLIKASI CD INTERAKTIF BELAJAR MICROSOFT EXCELL DI CSBI
}

\author{
Dion Eko Valentino, S.S., M.Kom. \\ Dosen Program Studi Manajemen Informatika \\ Politeknik LP3I Bandung \\ e-mail : dion.valentino@gmail.com
}

\begin{abstract}
Abstrak : CD Interaktif merupakan sebuah media yang menegaskan sebuah format multimedia dapat dikemas dalam sebuah CD (Compact Disk) dengan tujuan aplikasi interaktif didalamnya. CD ROM (Read Only Memory) merupakan satu-satunya dari beberapa kemungkinan yang dapat menyatukan suara, video, teks, dan program CD. CD Interaktif adalah sebuah $\mathrm{CD}$ yang berisi menu-menu yang dapat diklik untuk menampilkan sebuah informasi tertentu. Dari sini jelas bahwa sistem interaktif yang dipakai CD Interaktif sama persis dengan sistem navigasi pada internet, hanya yang berbeda di sini adalah media yang dipakai keduanya. CD Interaktif memakai media off line berupa CD sementara Internet memakai media on line. Media pembelajaran saat ini sudah semakin beragam, mulai dari media konvensional seperti buku dan alat peraga tradisional sampai dengan media modern audio visual berupa kaset tape, VCD (Video Compact Disk), maupun alat paraga modern lainnya. Dengan beragam media tersebut, maka suatu sistem pembelajaran yang dapat menghadirkan suasana menyenangkan mutlak diperlukan. Oleh karena itu tidak salah jika CD Interaktif merupakan salah satu alternatif media yang dapat menjawab kebutuhan tersebut.
\end{abstract}

Kata Kunci : CD Interaktif, Microsoft Excell, Video Compact Disk

\section{Pendahuluan}

Excel merupakan program spread sheet pertama yang mengizinkan pengguna untuk mendefinisikan bagaimana tampilan dari spreadsheet yang mereka sunting: font, atribut karakter, dan tampilan setiap sel. Excel juga menawarkan penghitungan kembali terhadap sel-sel secara cerdas, di mana hanya sel yang berkaitan dengan sel tersebut saja yang akan diperbarui nilanya (dimana program-program spreadsheet lainnya akan menghitung ulang keseluruhan data atau menunggu perintah khusus dari pengguna). Selain itu, Excel juga menawarkan fitur pengolahan grafik yang sangat baik.

Citra Sarana Bahasa dan Informatika (CSBI) adalah sebuah lembaga les privat yang beralamat di jalan pahlawan no. 28 Bandung. Bidang yang tersedia yaitu komputer dan bahasa asing. Dibidang komputer, tersedia materi les seperti komputer perkantoran, komputer desain grafis, komputer akuntansi, pemrograman, autocad 2009, animasi 3D, dan desain web macromedia. Dan dibidang bahasa, CSBI menyediakan materi les Bahasa inggris, English conversation, bahasa mandarin, bahasa jepang, bahasa jerman, bahasa perancis dan bahasa korea.

CD Interaktif merupakan sebuah media yang menegaskan sebuah format multimedia dapat dikemas dalam sebuah CD (Compact Disk) dengan tujuan aplikasi interaktif didalamnya. CD ROM (Read Only Memory) merupakan satu-satunya dari beberapa kemungkinan yang dapat menyatukan suara, video, teks, dan program CD. CD Interaktif adalah sebuah CD yang berisi menu-menu yang dapat diklik untuk menampilkan sebuah informasi tertentu. Dari sini jelas bahwa sistem interaktif yang dipakai CD Interaktif sama persis dengan sistem navigasi pada internet, hanya yang berbeda di sini adalah media 
yang dipakai keduanya. CD Interaktif memakai media off line berupa CD sementara Internet memakai media on line.

Media pembelajaran saat ini sudah semakin beragam, mulai dari media konvensional seperti buku dan alat peraga tradisional sampai dengan media modern audio visual berupa kaset tape, VCD (Video Compact Disk), maupun alat paraga modern lainnya. Dengan beragam media tersebut, maka suatu sistem pembelajaran yang dapat menghadirkan suasana menyenangkan mutlak diperlukan. Oleh karena itu tidak salah jika CD Interaktif merupakan salah satu alternatif media yang dapat menjawab kebutuhan tersebut.

\section{Sistem Yang Bejalan}

Sistem yang berjalan di Citra Sarana Bahasa dan Informatika (CSBI), media pembelajaran masih menggunakan media buku sebagai modul pembelajaran. Dimana terdapat banyak terjadi kesalahan didalamnya. Beberapa kesalahan diantaranya, halaman yang hilang, huruf yang tidak terbaca, halaman terbalik, atau kata yang hilang/tertukar.

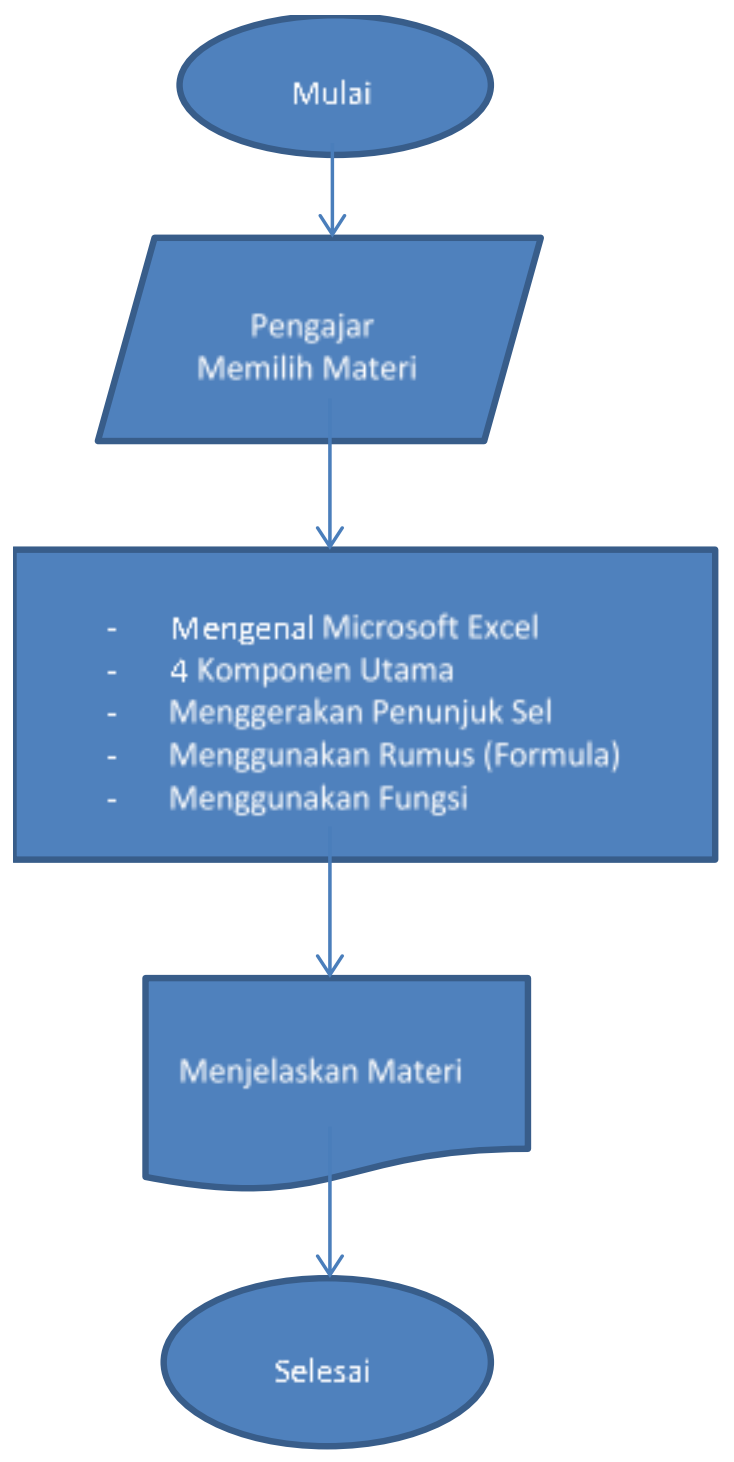

Gambar 1. Flowchart sistem yang ada 


\section{Kebutuhan Pengguna}

Penulis mengumpulkan data secara langsung terhadap objek yang ditinjau dan kemudian dianalisa secara lebih lanjut sebagai berikut:

\section{a. Media Belajar}

Penulis melihat media belajar yang digunakan di LKP Citra Sarana Bahasa dan Informatika masih menggunakan media buku sebagai modul, dimana terdapat banyak kesalahan didalamnya. Siswa membutuhkan media yang lebih simple dan lebih mudah dipelajari.

\section{b. Proses Belajar}

Penulis menilai proses belajar kurang efektif karena masih banyak siswa yang kurang mengerti dikarenakan materi didalam modul yang masih memiliki berbagai kesalahan sehingga lebih memakan waktu. Tidak adanya video tutorial yang dapat mempermudah siswa mempelajari materi. Siswa membutuhkan proses belajar yang lebih cepat dan mudah dipahami.

Dari berbagai permasalahan diatas makan penulis menyimpulkan yang perusahaan butuhkan adalah sebagai berikut:

a. Membuat Aplikasi CD interaktif berbasis multimedia sebagai media belajar microsoft excel di CSBI.

b. Menggunakannya untuk proses belajar mengajar di CSBI

c. Menggunakannya untuk media belajar yang sebelumnya menggunakan media buku sebagai modul menjadi CD interaktif.

\section{Ruang Lingkup}

Pembatasan masalah dimaksudkan untuk memberikan titik fokus pembahasan dan memberikan arahan yang lebih jelas, batasan masalah untuk penelitian ini adalah :

a. Pembuatan Aplikasi CD Interaktif berbasis multimedia sebagai media belajar microsoft excel di CSBI.

b. CD Interaktif ini berisi tentang materi pembelajaran microsoft excel di Citra Sarana Bahasa dan Informatika.

c. Perangkat lunak yang digunakan dalam pembuatan CD Interaktif ini adalah:

1) Adobe Flash CS5

2) Corel Draw X6

3) Adobe Photoshop CS5

4) Corel Video Studio $X 7$

\section{Manfaat Produk}

Adapun manfaat dari produk yang akan dirasakan oleh pengguna adalah :

1. Terlihat berbeda dan terkesan lebih mudah dipahami

2. Mempermudah siswa untuk mempelajari materi karena juga disertai dengan video tutorial.

3. Materi dilengkapi dengan visualisasi, audio dan animasi.

4. Materi bisa dipelajari dimanapun.

\section{Pembahasan}

\subsection{Analisis Data}

Setelah melakukan penelitian yang berhubungan dengan sistem belajar mengajar di Citra Sarana Bahasa dan Informatika, dapat diketahui bahwa sistem belajar mengajar masih 
manual dan berpatok pada modul. Peserta atau murid les akan memperhatikan penjelasan dari pengajar tentang materi yang dipelajari. Lalu mereka melihat modul untuk mambaca dan memahami gambar dari langkah - langkah materi yang dipelajari. Oleh karena itu penulis merancang CD interaktif berbasis multimedia sebagai media pembelajaran di Citra Sarana Bahasa dan Informatika. Dalam perancangan CD interaktif berbasis multimedia sebagai media pembelajaran ini, penulis membuat sebuah video tutorial yang dikemas dalam aplikasi Adobe flash dimana para peserta les dapat lebih mudah mempelajari materi. Sehingga tidak perlu lagi berpatok pada modul dimana sering terdapat beberapa kesalahan didalamnya.

\section{Perancangan Sitemap}

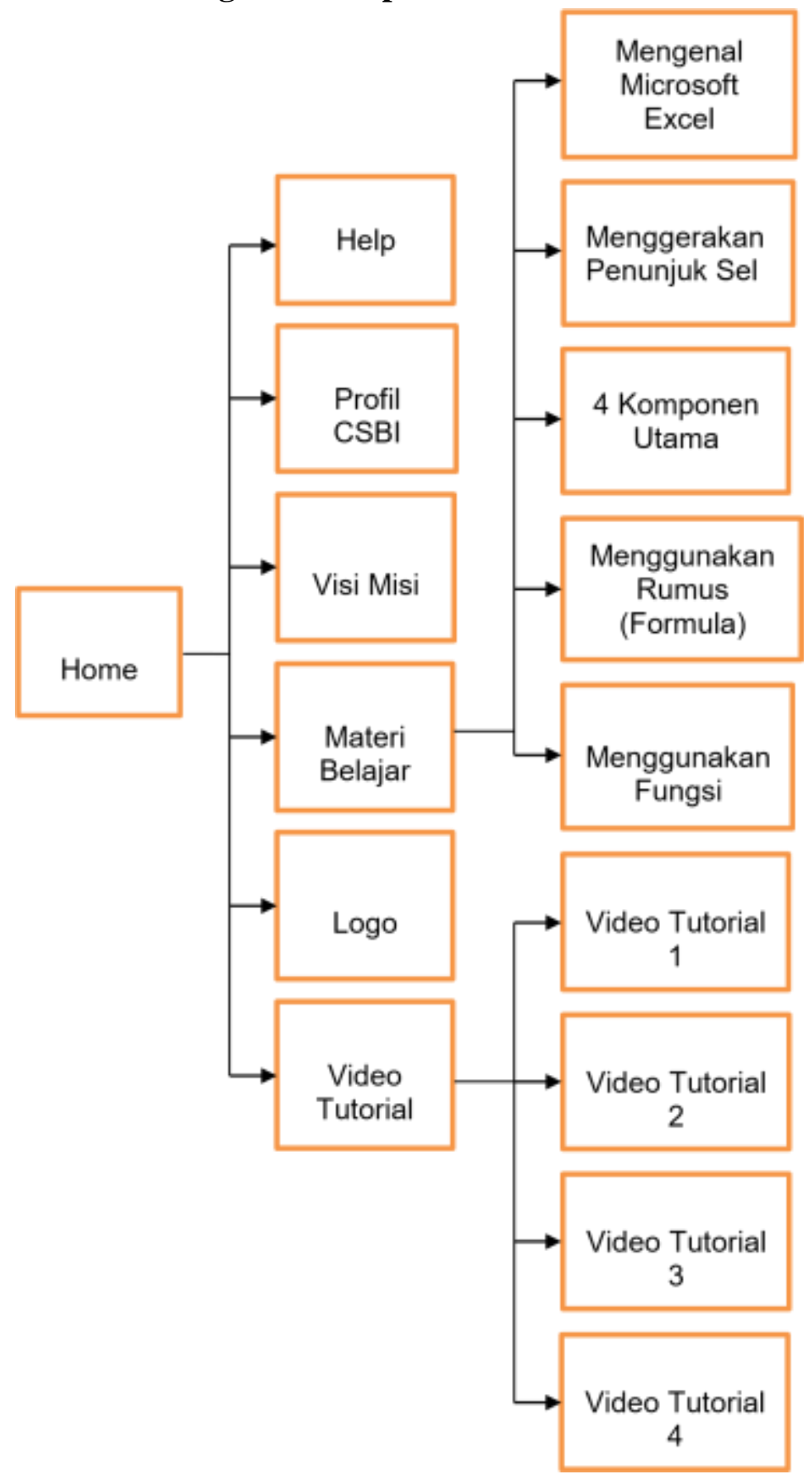

\section{Perancangan Flowchart}

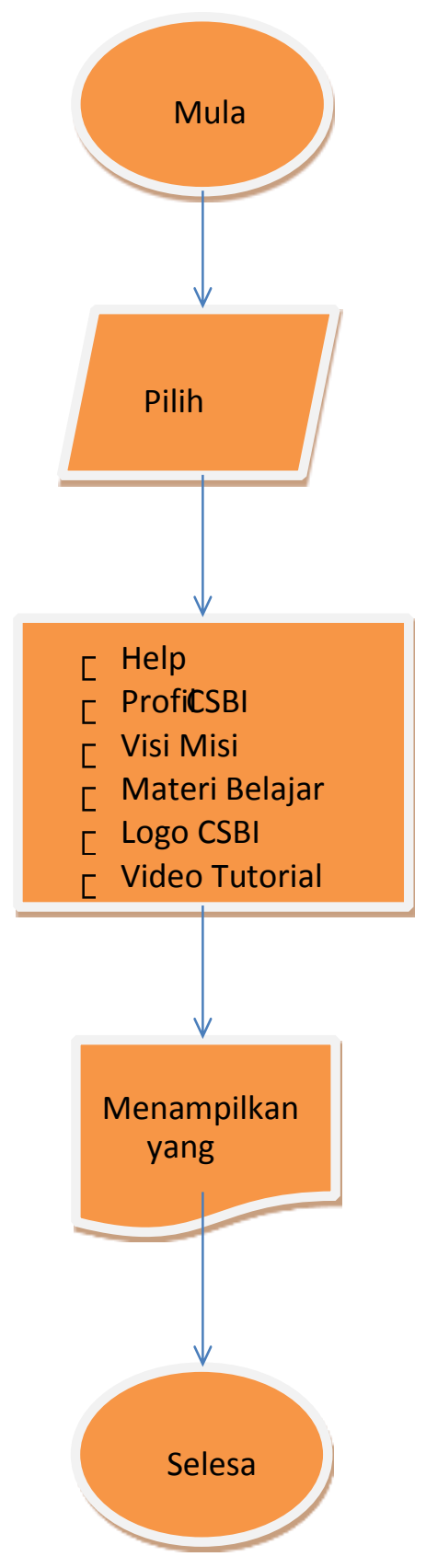




\section{Use Case}

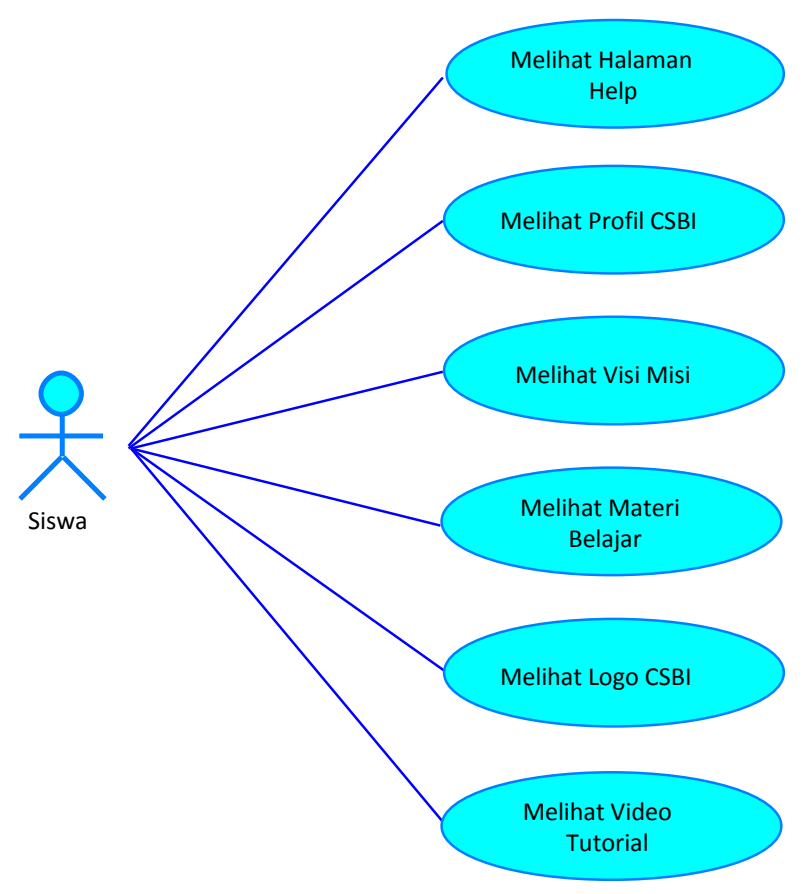

\section{Sequence Diagram}

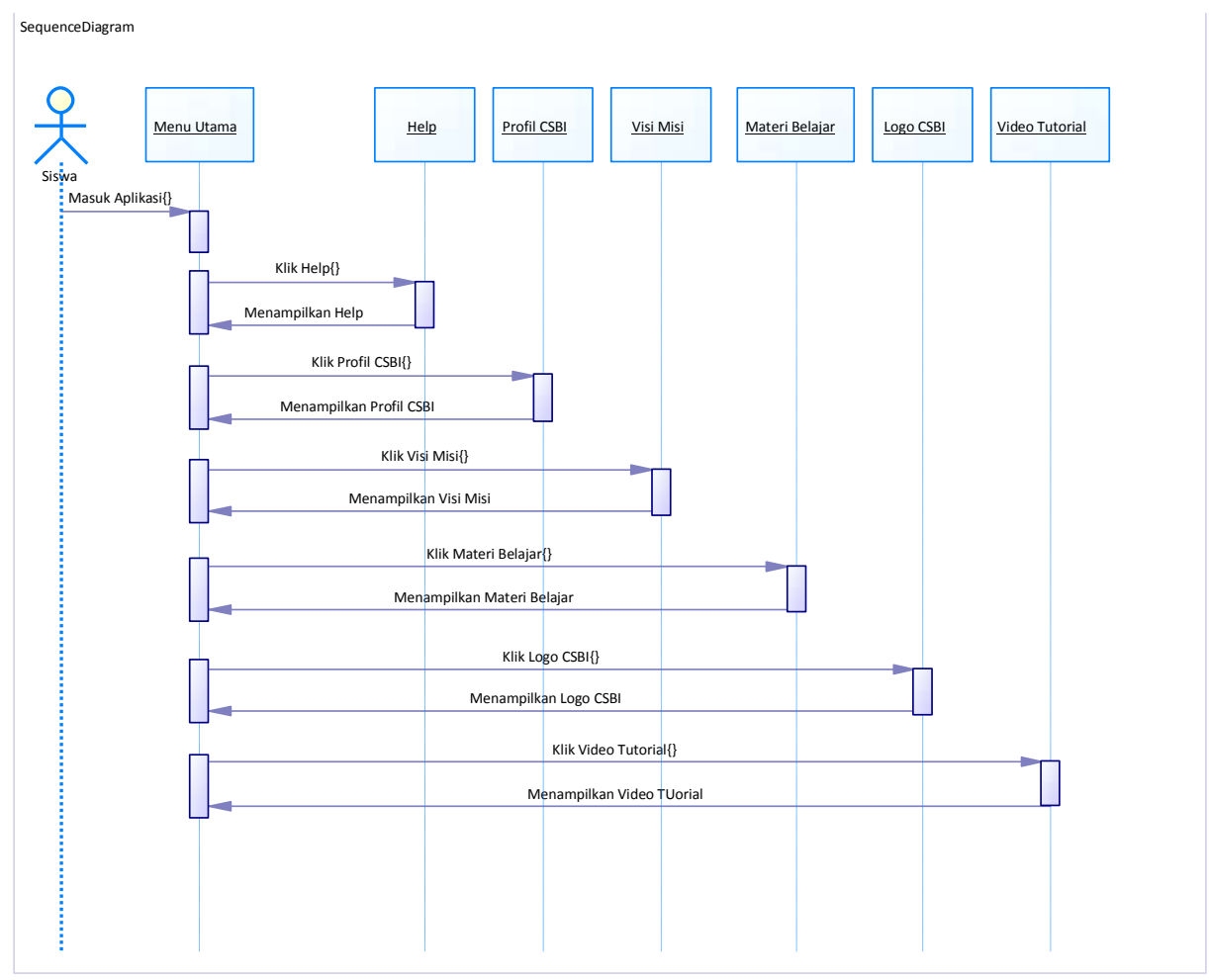




\section{Perancangan Storyboard}

\section{Home}

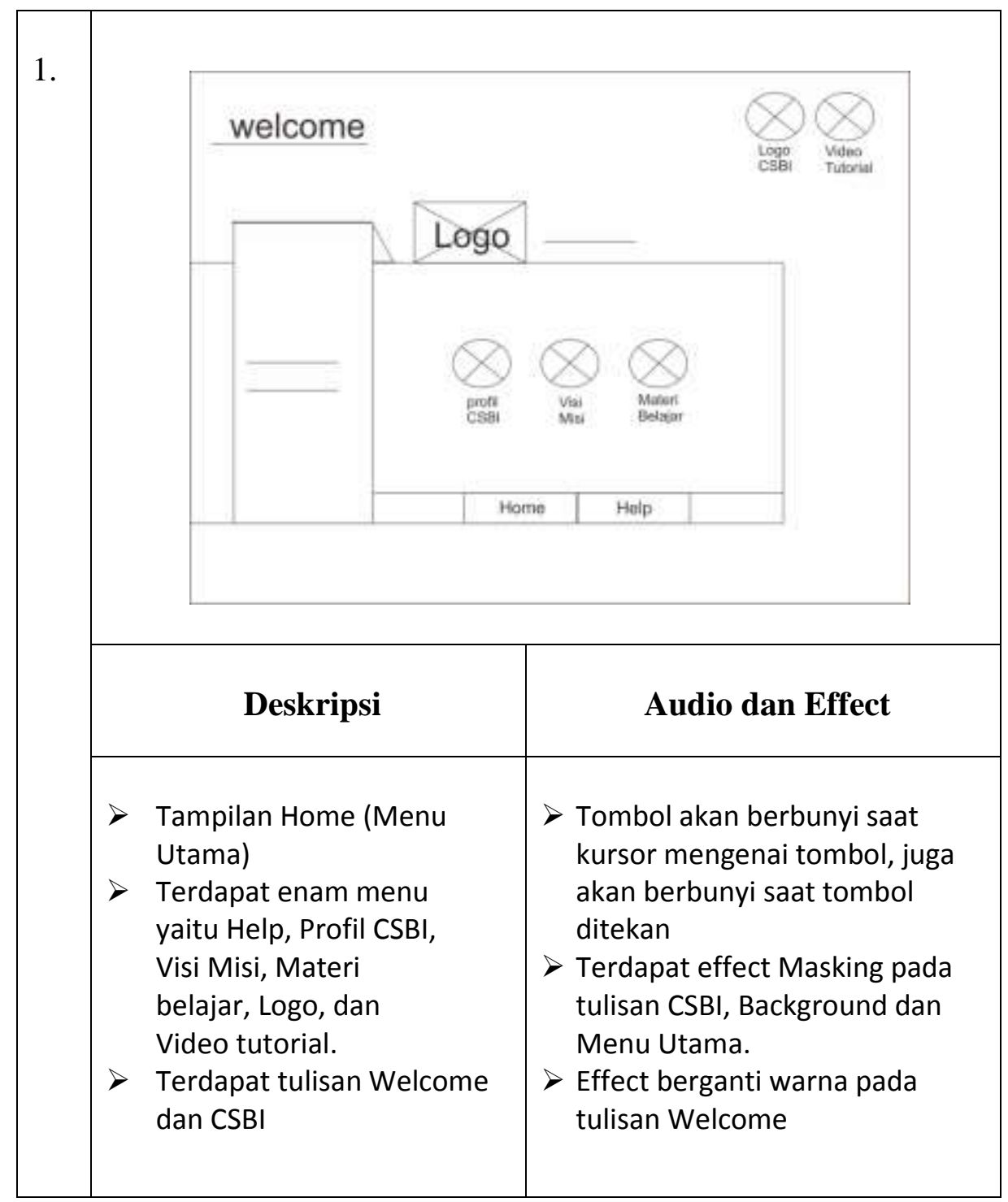


Help

\begin{tabular}{|c|c|c|}
\hline 2. & \\
\hline
\end{tabular}




\section{Halaman Profil CSBI}

\begin{tabular}{|l|l|}
\hline & \\
\hline
\end{tabular}




\section{Halaman Visi Misi}

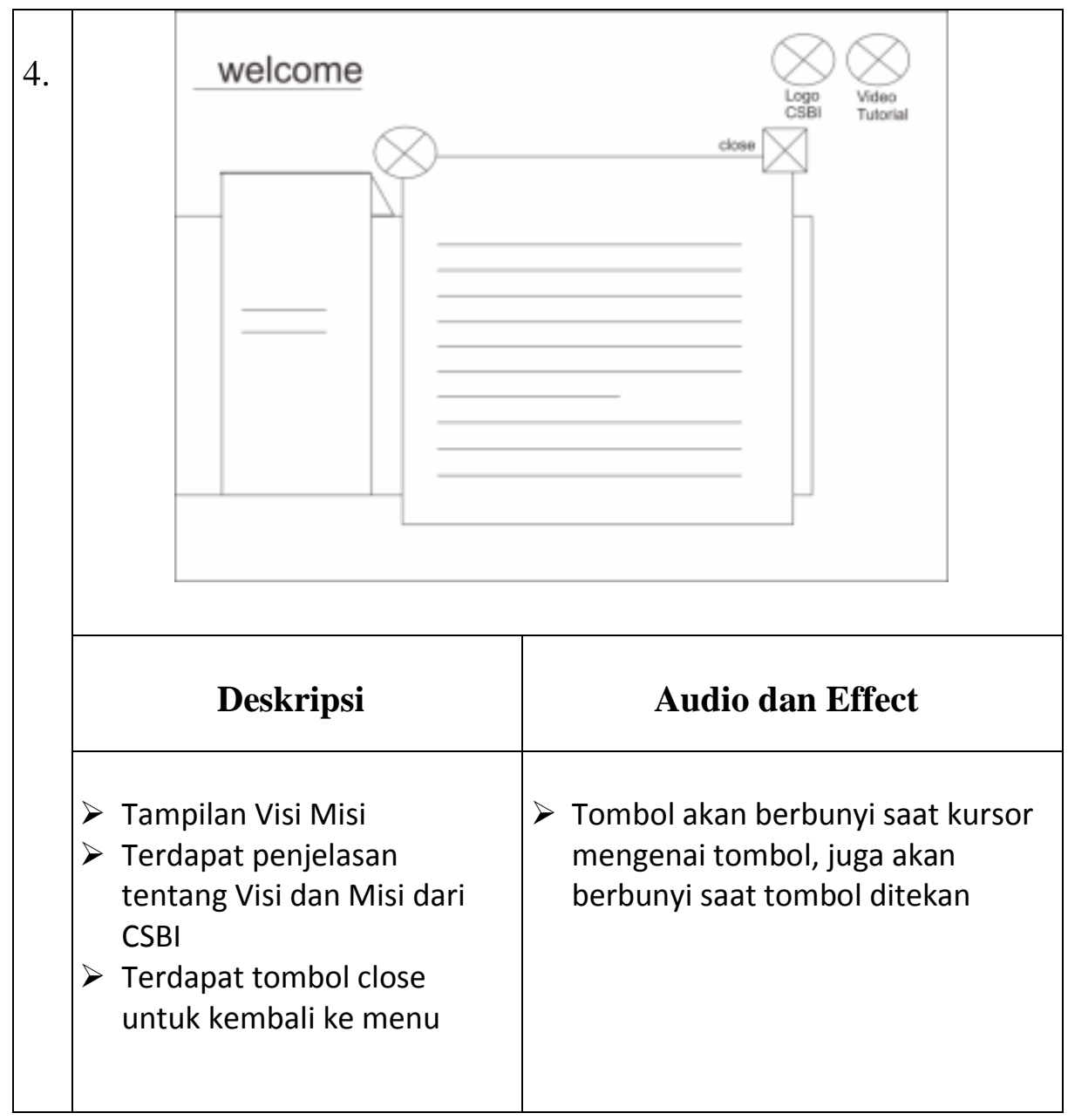


Halaman Materi Belajar

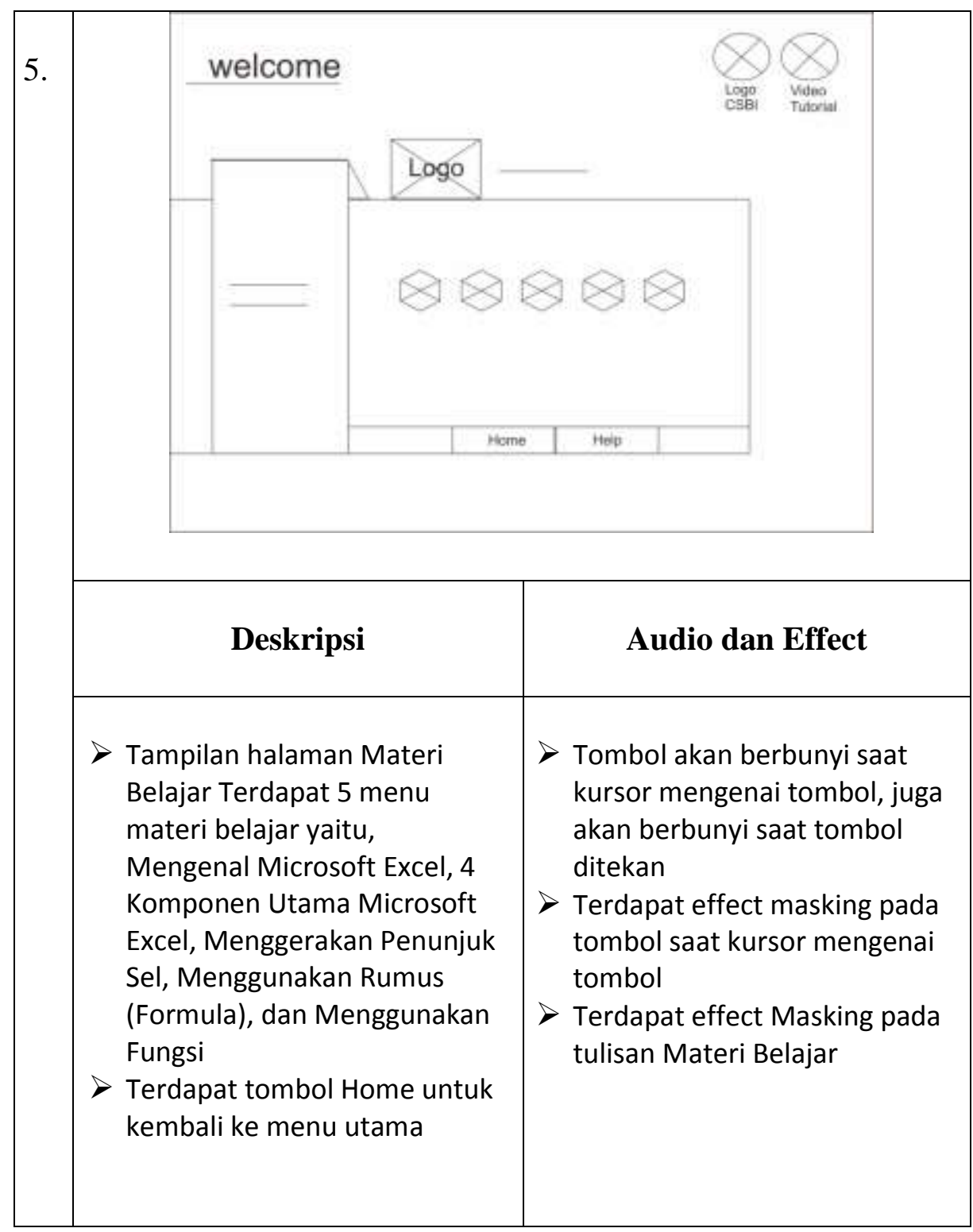




\section{Halaman Mengenal Microsoft Excel}

\begin{tabular}{|l|l|l|}
\hline $6 . \mid$ & \\
\hline
\end{tabular}


Halaman 4 Komponen Utama Microsoft Excel

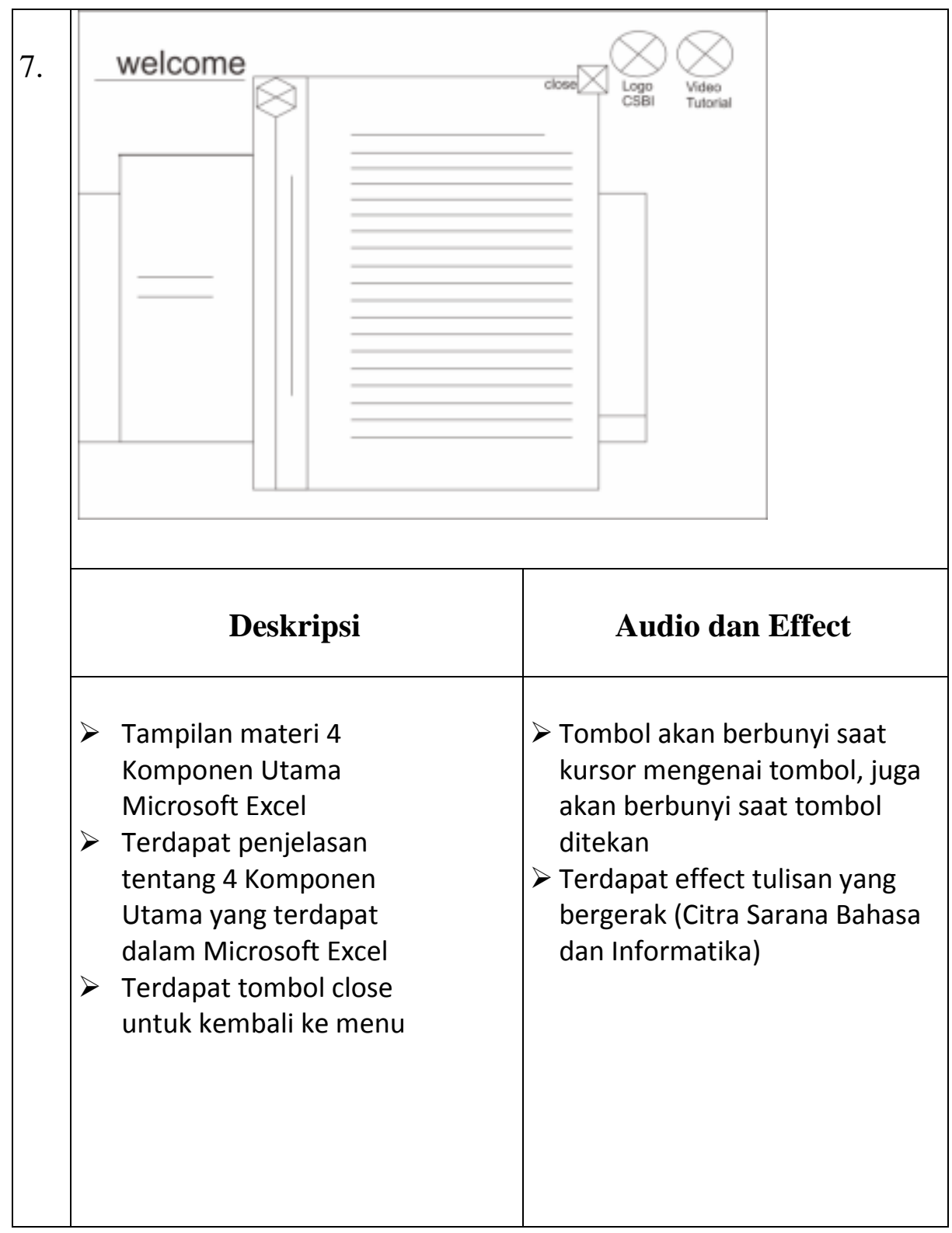




\section{Halaman Menggerakan Penunjuk Sel}

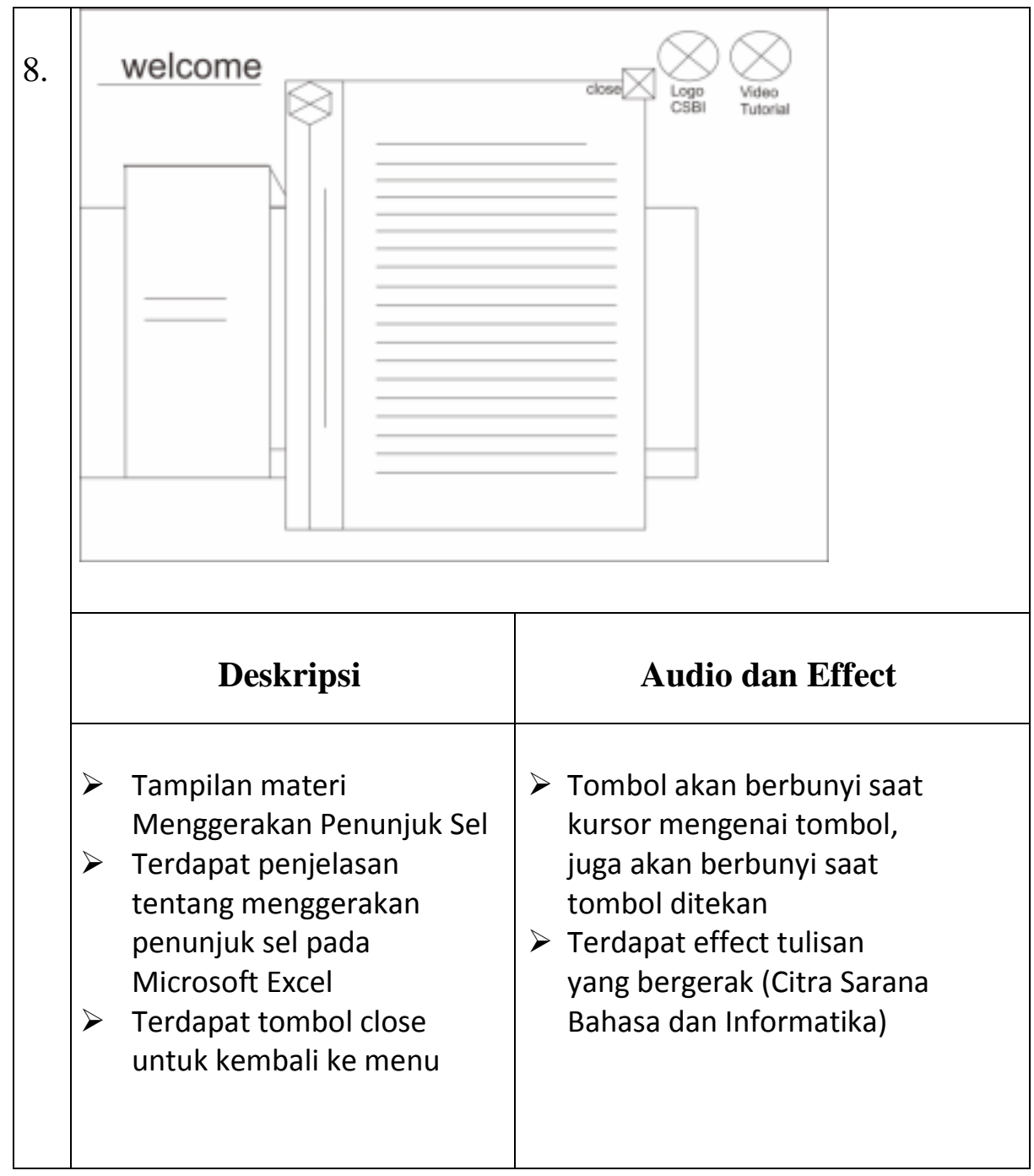




\section{Halaman Menggunakan Rumus (Formula)}

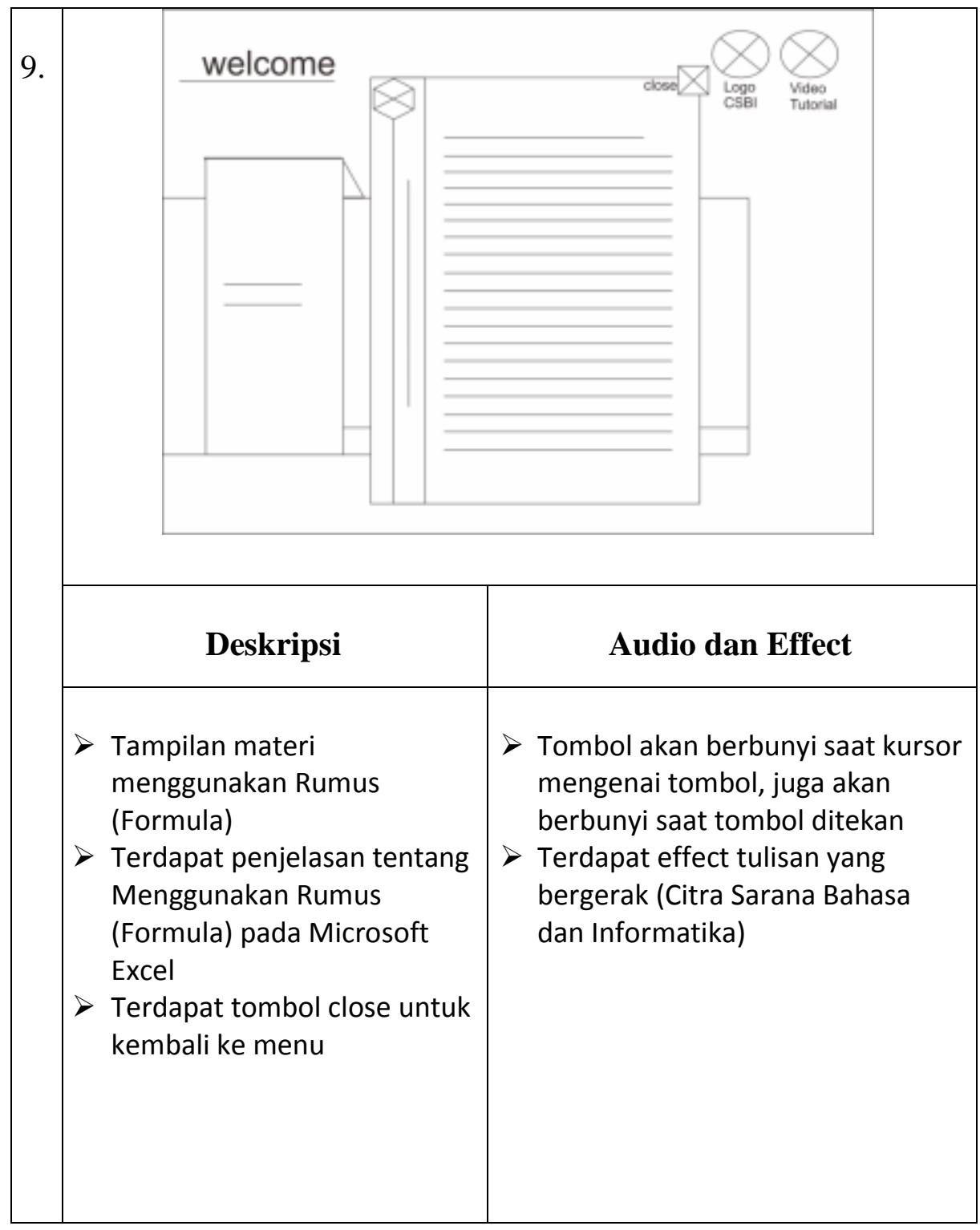




\section{Halaman Menggunakan Fungsi bagian 1}

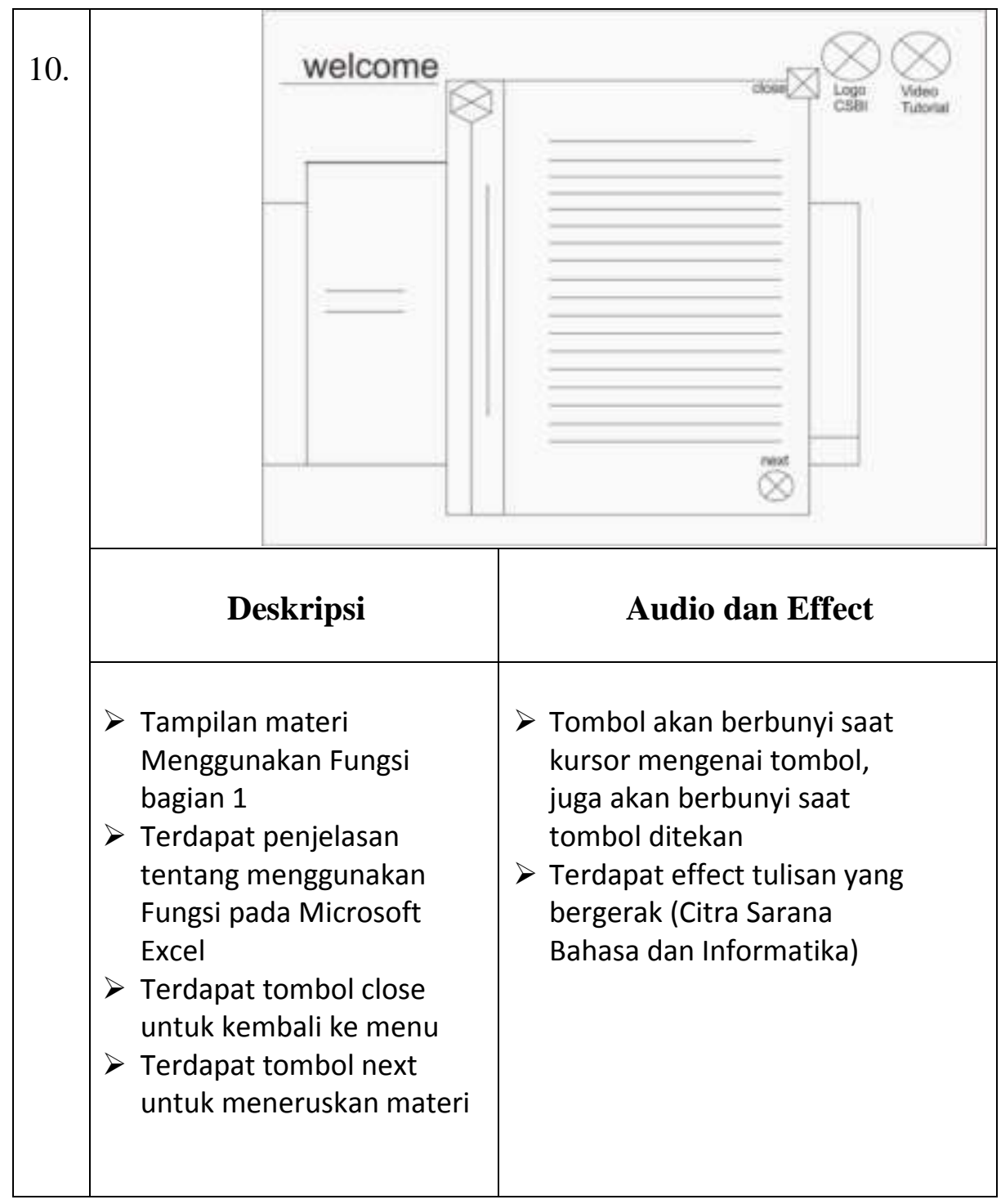




\section{Halaman Menggunakan Fungsi bagian 2}

\begin{tabular}{|l|l|l|}
\hline 11. & \\
\hline
\end{tabular}




\section{Halaman Menggunakan Fungsi bagian 3}

\begin{tabular}{|l|l|}
\hline 12 & \\
\hline
\end{tabular}




\section{Halaman Logo CSBI}

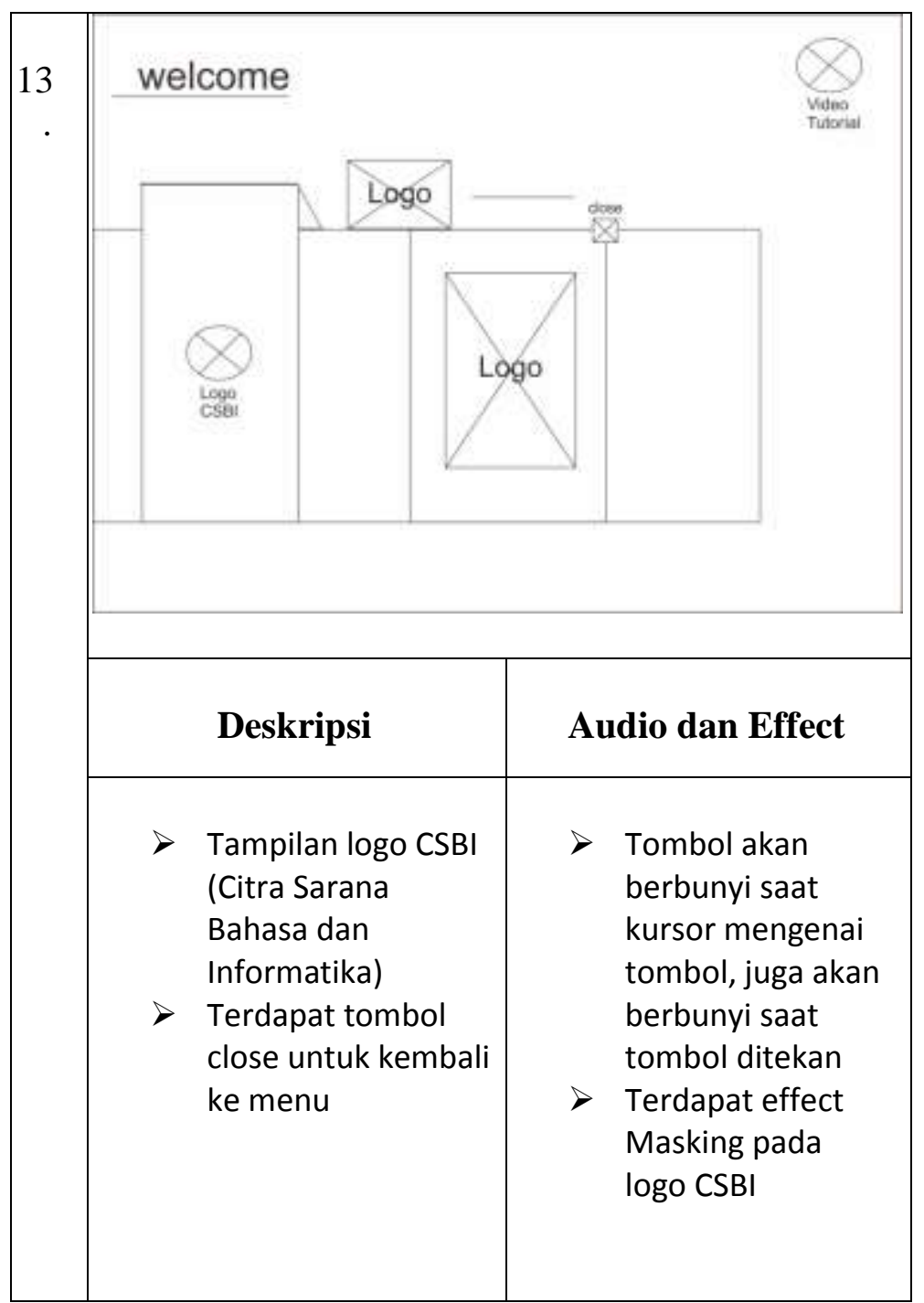




\section{Halaman Video Tutorial}

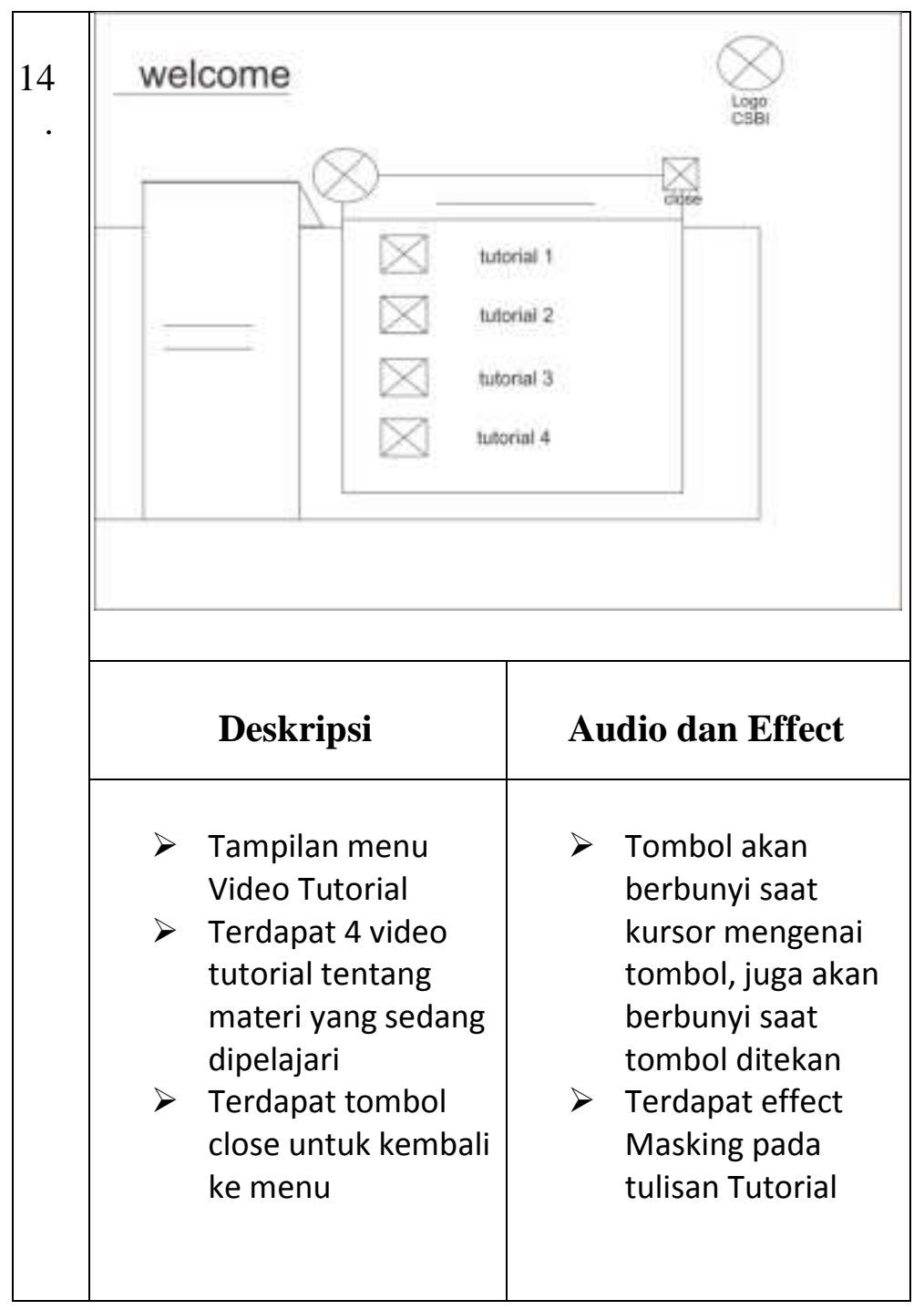

\section{Spesifikasi Software dan Hardware}

1. Software

Operating System Windows 7 32-bit

2. Hardware

Prosesor : Pentium IV atau diatasnya

Ram : 1 GB (recomended : 2GB atau lebih)

VGA : $512 \mathrm{MB}$ (recomended : $1024 \mathrm{MB}$ atau lebih) 


\section{IMPLEMENTASI}

\section{Implementasi Produk}

Dalam implementasi perancangan CD Interaktif Berbasis Multimedia Sebagai Media Pembelajaran di CSBI, penulis menggunakan perangkat lunak Adobe Flash CS5 serta Microsoft Excel sebagai materi yang tengah dipelajari.

\section{a. Perangkat Lunak Adobe Flash CS5}

Dalam pembuatan CD interaktif berbasis multimedia sebagai media pembelajaran Citra Sarana dan Informatika (CSBI) penulis menggunakan perangkat lunak Adobe Flash CS5. Adobe Flash CS5 merupakan sebuah program yang didesain khusus oleh Adobe dan program aplikasi standar authoring tool professional yang digunakan untuk membuat animasi dan bitmap yang sangat menarik untuk keperluan pembangunan situs web yang interaktif dan dinamis.

\section{b. Perangkat Lunak Microsoft Excel}

Microsoft Office Excel adalah sebuah program aplikasi lembar kerja spreadsheet yang dibuat dan didistribusikan oleh Microsoft Corporation yang dapat dijalankan pada Microsoft Windows dan Mac OS. Aplikasi ini memiliki fitur kalkulasi dan pembuatan grafik yang, dengan menggunakan strategi marketing Microsoft yang agresif, Excel merupakan program spreadsheet pertama yang mengizinkan pengguna untuk mendefinisikan bagaimana tampilan dari spreadsheet yang mereka sunting: font, atribut karakter, dan tampilan setiap sel.

\section{b. Tampilan Menu}

\section{Tampilan Menu Untuk siswa}

\section{Halaman Home}

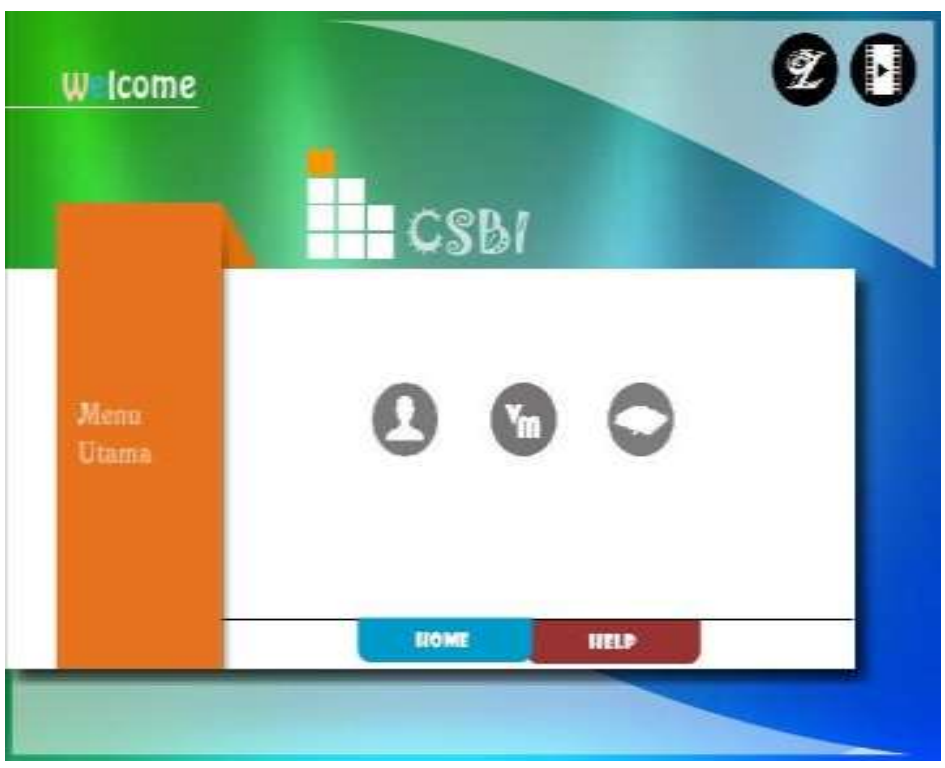

Tampilan halaman Home

Dalam halaman home terdapat 6 menu yaitu, menu Help, Profil CSBI, Visi Misi, Materi Belajar, Logo CSBI, dan Video Tutorial. Siswa juga bisa melihat 3 efek Masking yang terdapat pada tulisan CSBI, Menu Utama, dan background. Dan efek warna yang terdapat pada tulisan Welcome. 
Halaman Help

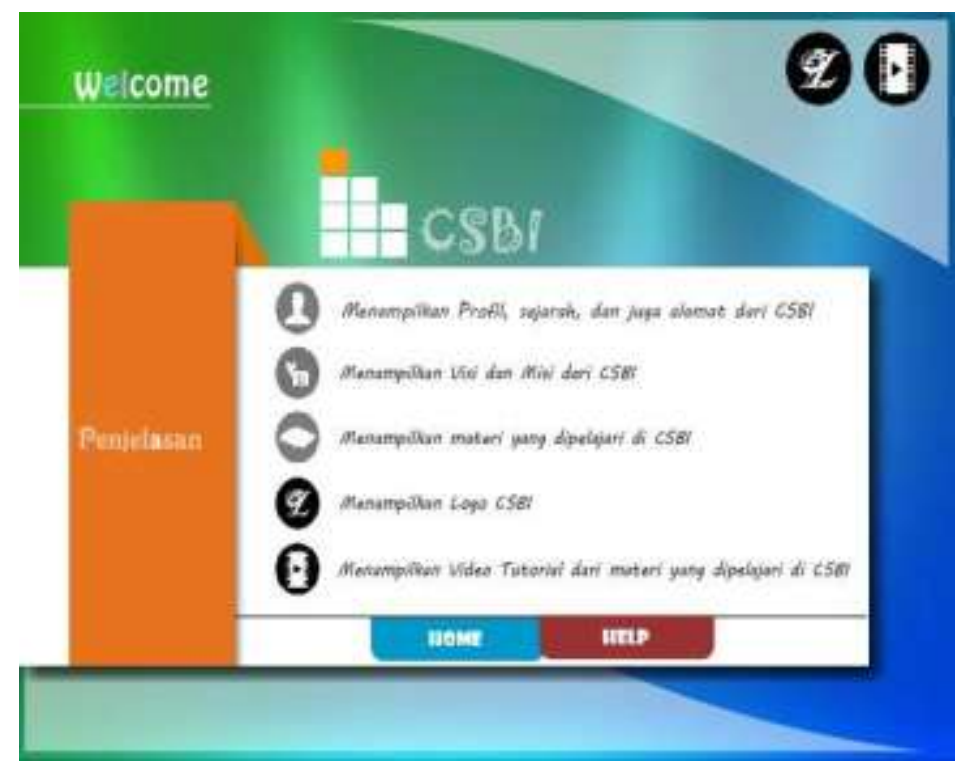

Tampilan halaman Help

Dalam halaman Help siswa bisa melihat tampilan penjelasan tentang menu-menu yang ada.

\section{Profil CSBI}

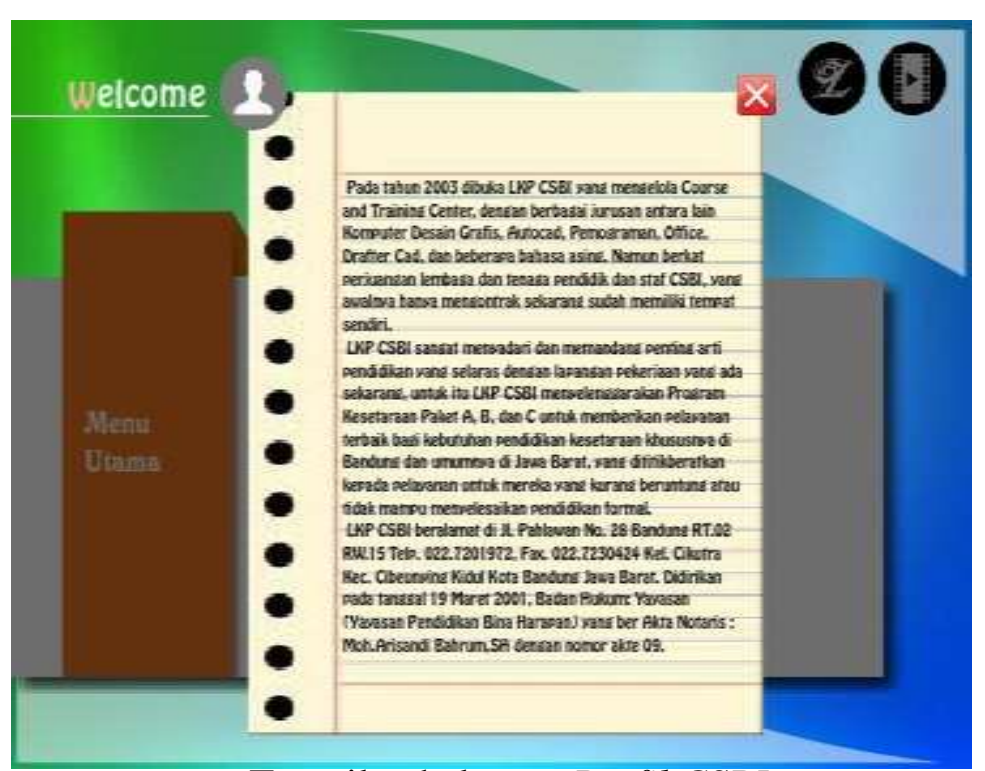

Tampilan halaman Profil CSBI

Dalam halaman Profil CSBI siswa bisa melihat rincian Profil dari LKP Citra Sarana Bahasa dan Informatika (CSBI), Sejarah hingga alamat CSBI. 
Visi Misi

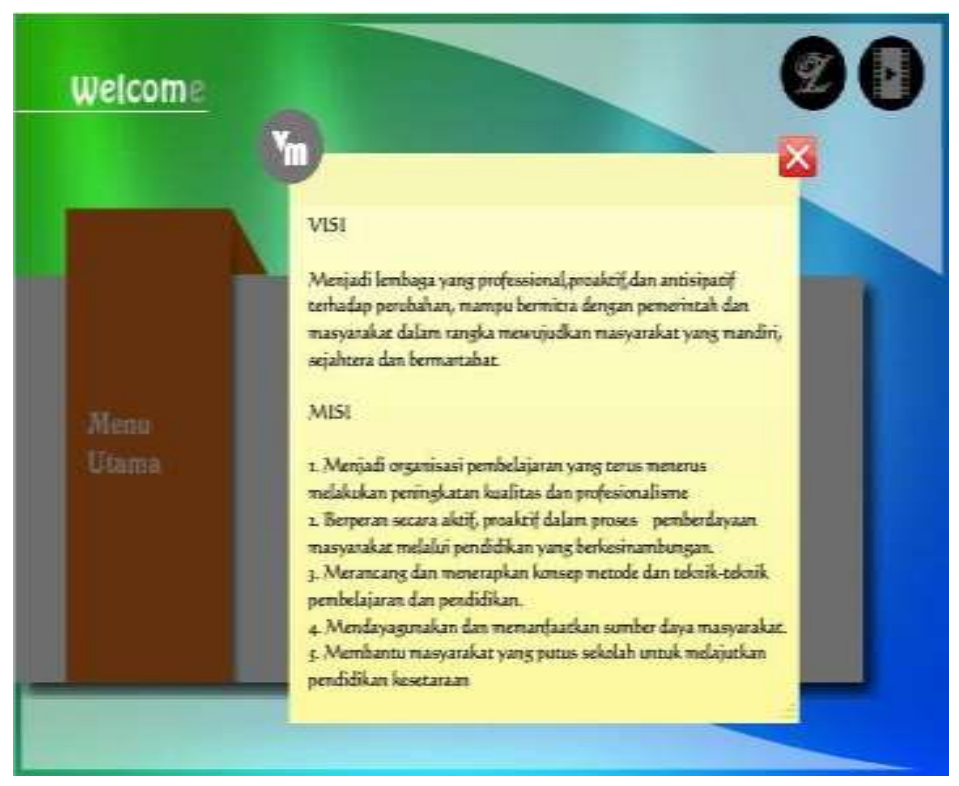

Tampilan halaman Visi Misi

Dalam halaman Visi Misi siswa bisa melihat Visi dan Misi dari LKP Citra Sarana Bahasa dan Informatika (CSBI).

\section{Materi Belajar}

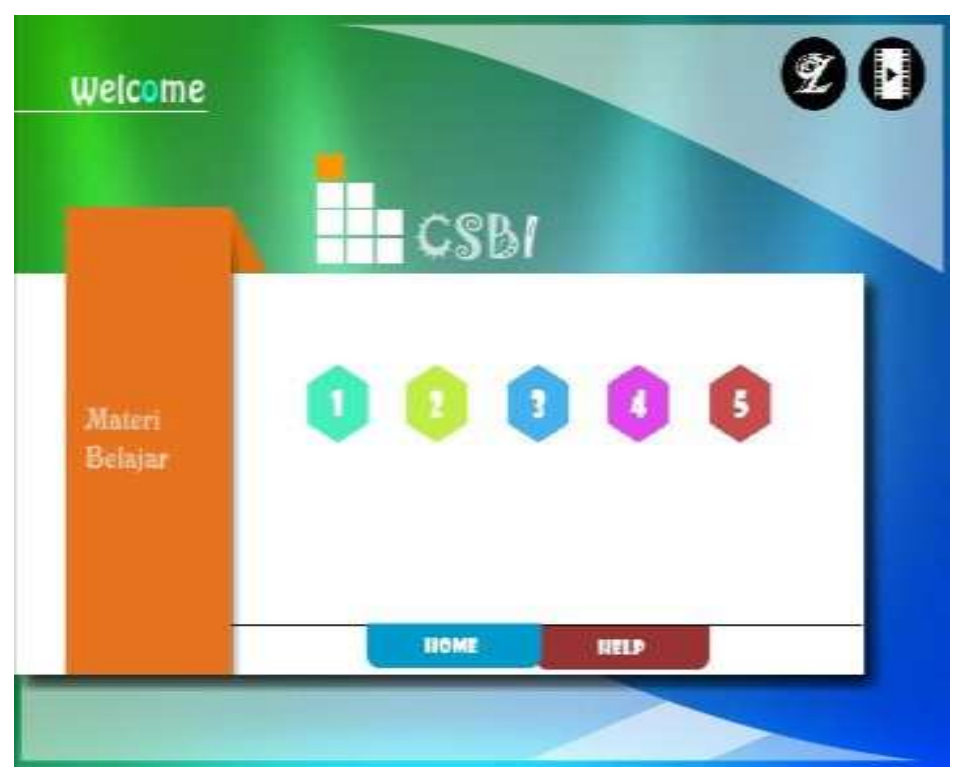

Tampilan halaman Materi Belajar

Dalam halaman Materi Belajar menampilkan 5 materi belajar yang sedang dipelajari di LKP Citra Sarana Bahasa dan Informatika (CSBI). Kelima materi tersebut yaitu, Mengenal Microsoft Excel, 4 Komponen Utama Microsoft Excel, Menggerakan Penunjuk Sel, Menggunakan Rumus (Formula), dan Menggunakan Fungsi. 
Halaman Mengenal Microsoft Excel

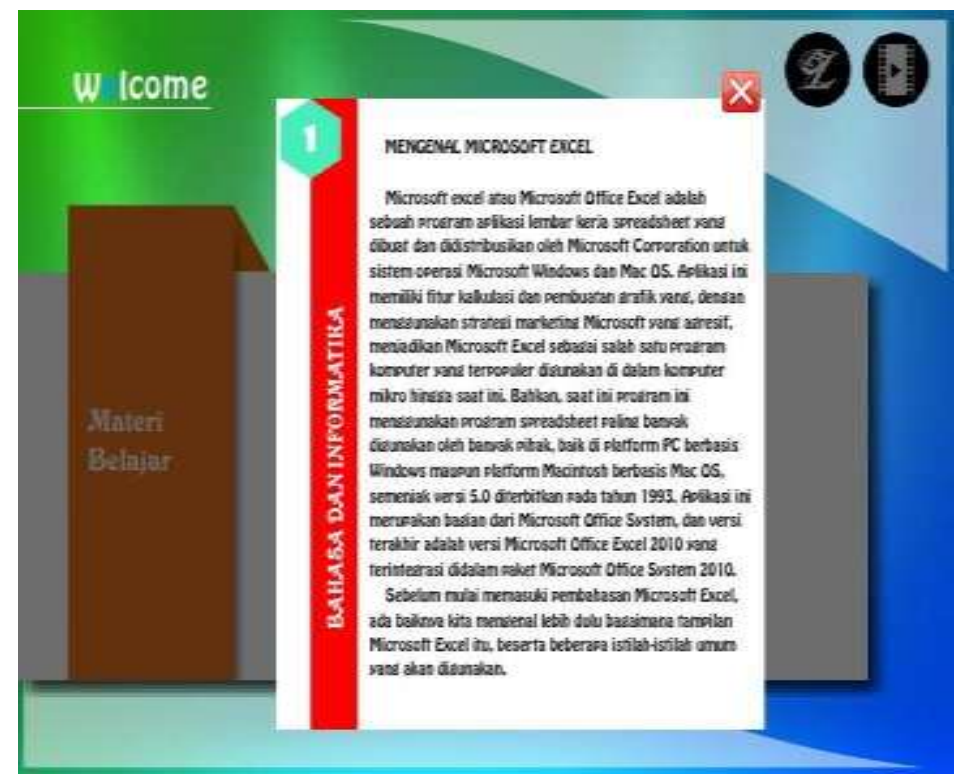

Tampilan halaman Mengenal Microsoft Excel

Dalam halaman Mengenal Microsoft Excel menampilkan penjelasan tentang Microsoft Excel atau Microsoft Office Excel. Siswa juga akan melihat efek tulisan Citra Sarana Bahasa dan Informatika.

Halaman 4 Komponen Utama Microsoft Excel

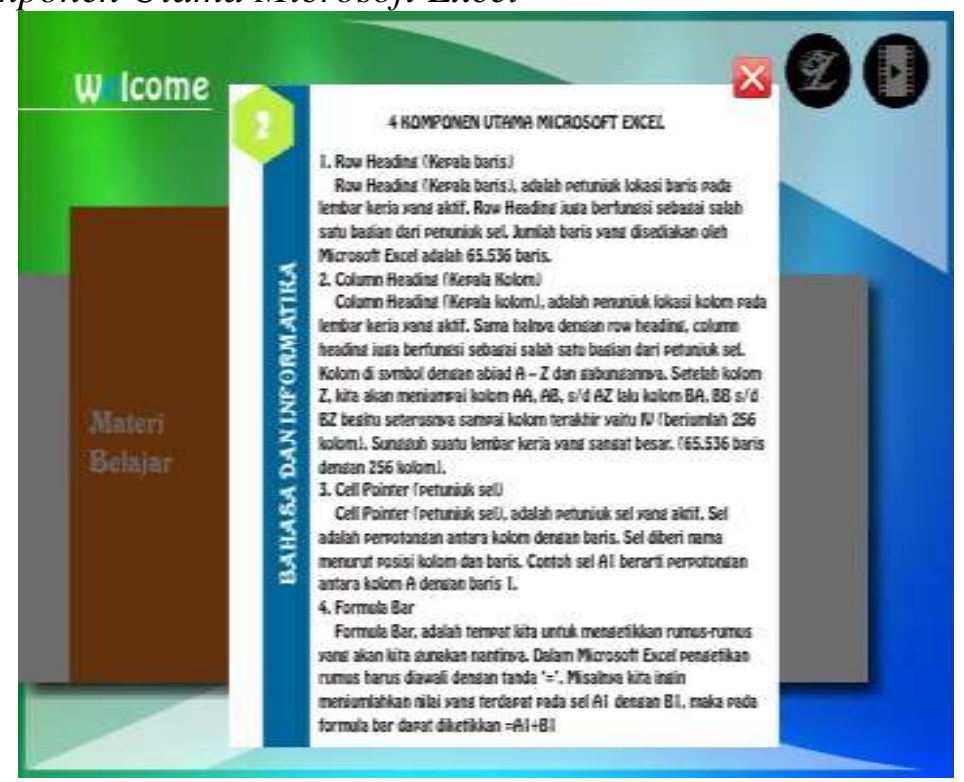

Tampilan halaman 4 Komponen Utama Microsoft Excel

Dalam halaman 4 Komponen Utama Microsoft Excel menampilkan materi tentang 4 Komponen Utama yang terdapat pada Microsoft Excel. Yang terdiri dari Row Heading, 
Column Heading, Cell Pointer, dan Formula Bar. Siswa juga akan melihat efek tulisan Citra Sarana Bahasa dan Informatika.

Halaman Menggerakan Penunjuk Sel

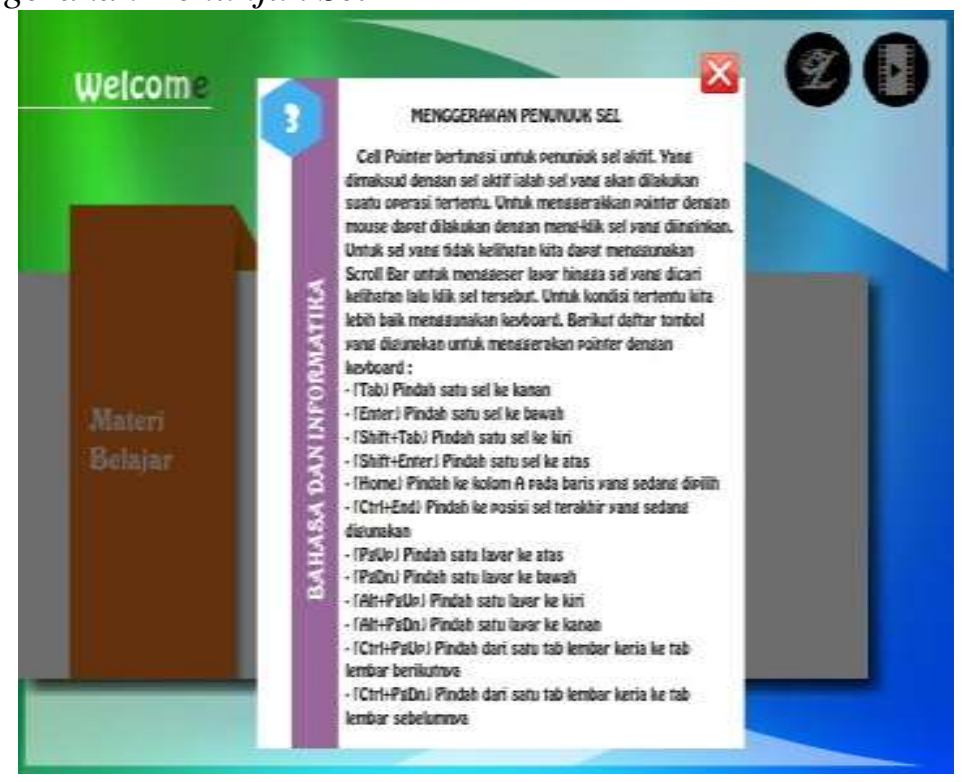

Tampilan halaman Menggerakan Penunjuk Sel

Dalam Halaman Menggerakan Penunjuk Sel menampilkan materi tentang bagaimana Menggerakan sel menggunakan keyboard. Tombol yang digunakan diantaranya : Tab, Enter, Shift+Tab, Shift+Enter, Home, Ctrl+End, PgUp, PgDn, Ctrl+PgUp, dan $\mathrm{Ctrl}+\mathrm{PgDn}$.

\section{Halaman Menggunakan Rumus (Formula)}

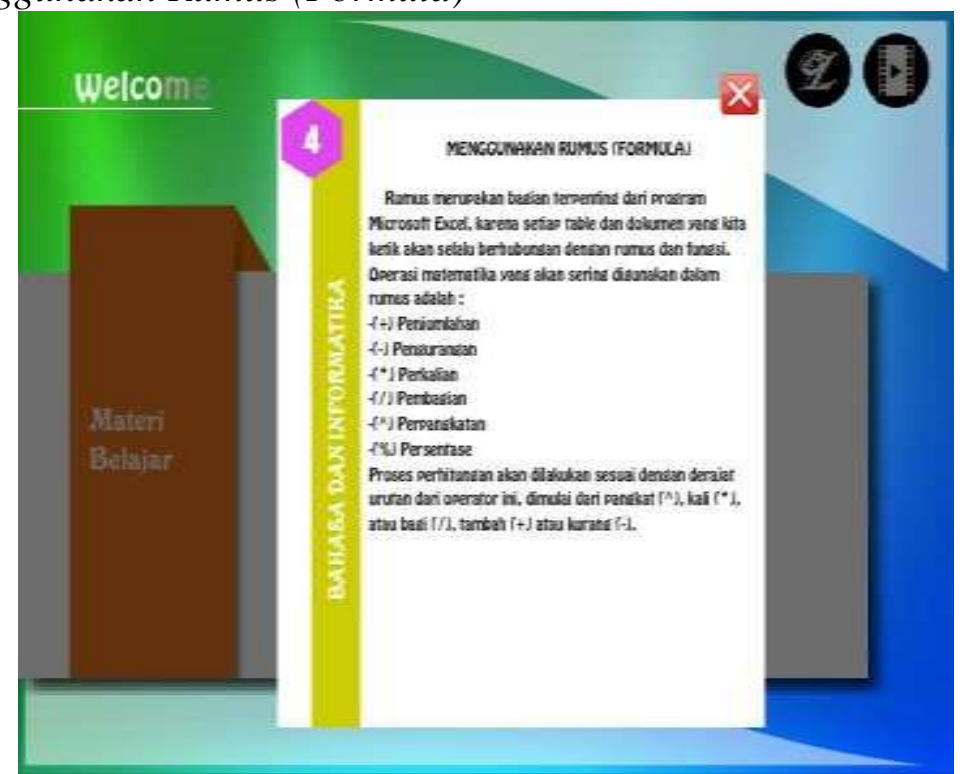

Tampilan halaman Menggunakan Rumus (Formula) 
Dalam Halaman Menggunakan Rumus (Formula) menampilkan materi tentang bagaimana Menggunakan Rumus (Formula) pada Microsoft Excel. Operasi matematika yang sering digunakan dalam rumus diantaranya : Penjumlahan(+), Pengurangan(-), Perkalian(*), Pembagian(/), Perpangkatan $(\wedge)$, dan Presentase $(\%)$.

\section{Halaman Menggunakan Fungsi}

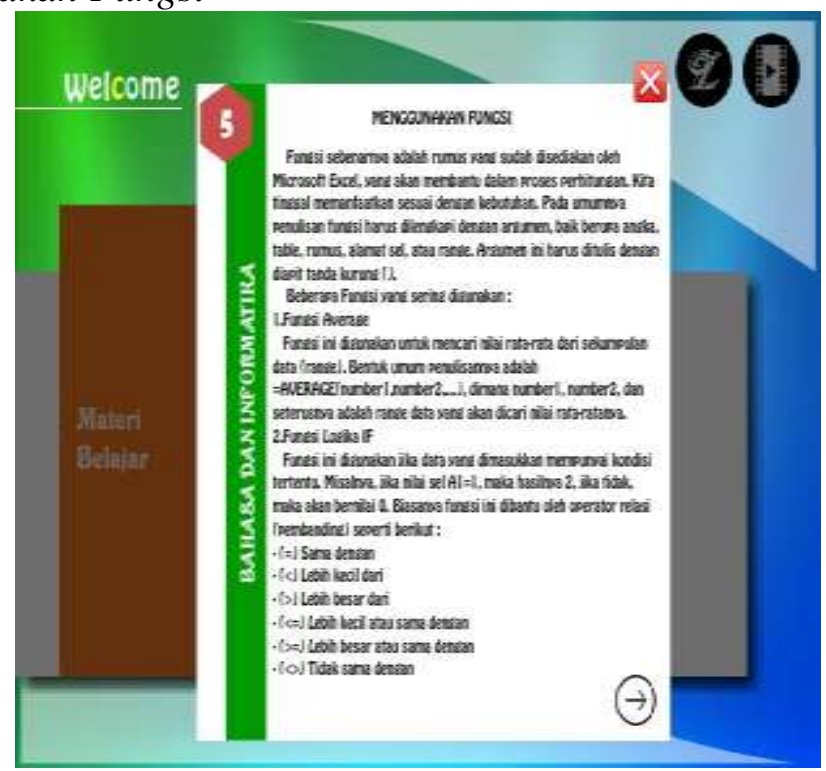

Tampilan halaman Menggunakan Fungsi bagian 1

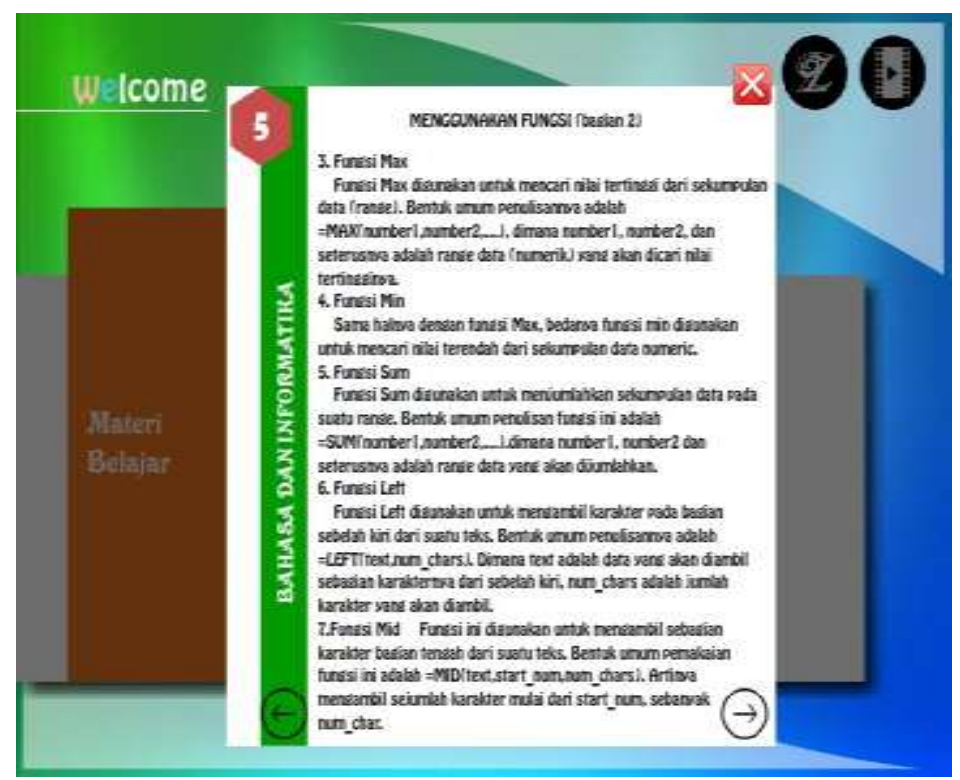

Tampilan halaman Menggunakan Fungsi bagian 2 


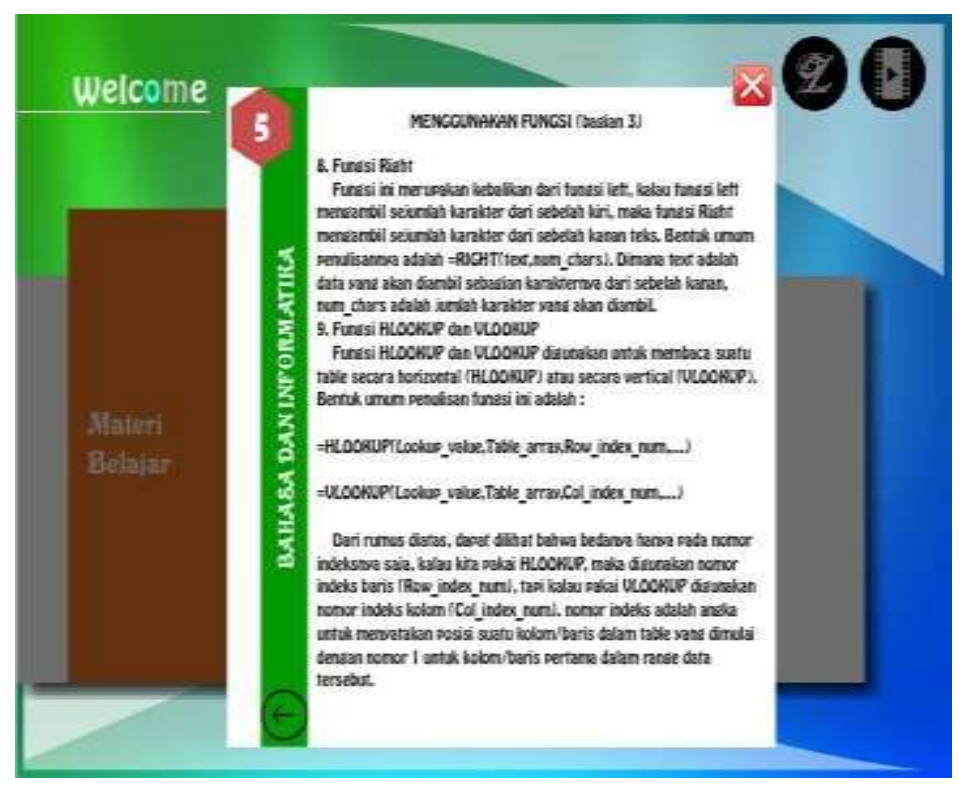

Tampilan halaman Menggunakan Fungsi bagian 3

Dalam halaman Menggunakan Fungsi menampilkan materi tentang bagaimana menggunakan fungsi di Microsoft Excel. Ada beberapa fungsi yang sering digunakan, yaitu Fungsi Average, Fungsi Logika IF, Fungsi Max, Fungsi Min, Fungsi Sum, Fungsi Left, Fungsi Mid, Fungsi Right, serta Fungsi HLOOKUP dan VLOOKUP. Karena materi yang cukup banyak sehingga materi menggunakan fungsi ini terbagi menjadi 3 halaman. Dimana pada halaman pertama terdapat tombol next untuk meneruskan ke halaman berikutnya, dan juga pada halaman kedua terdapat tombol next untuk meneruskan ke halaman berikutnya.

\section{Halaman Logo CSBI (Citra Sarana Bahasa dan Informatika)}

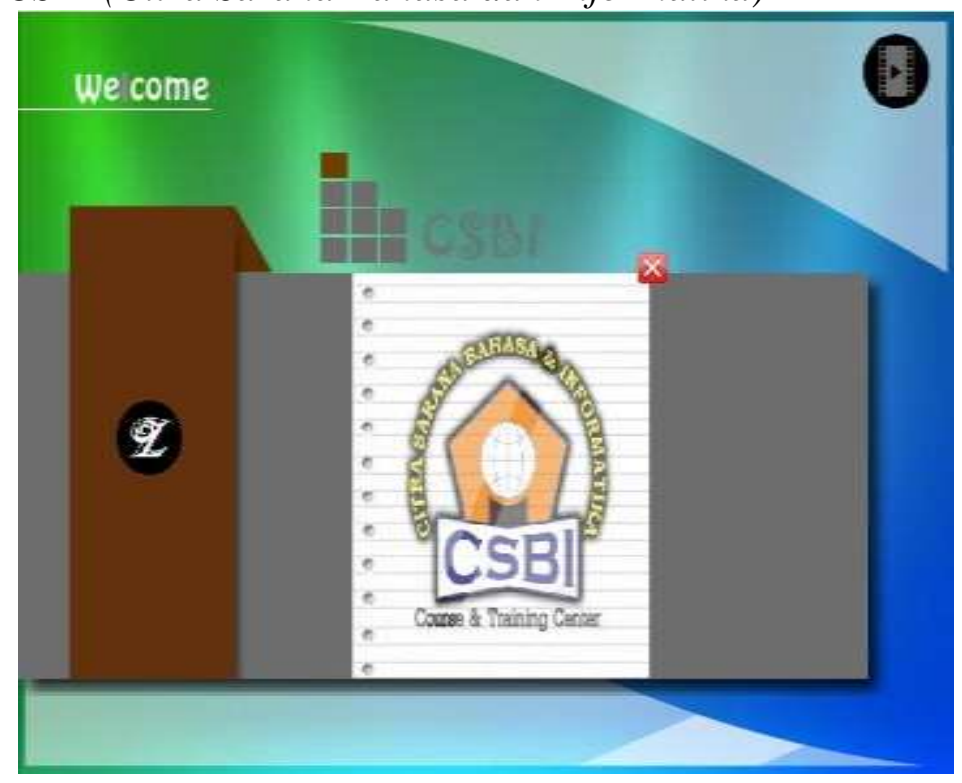

Tampilan halaman Logo Citra Sarana Bahasa dan Informatika (CSBI) 
Dalam halaman Logo CSBI siswa bias melihat logo dari LKP Citra Sarana Bahasa dan Informatika (CSBI).

Halaman Video Tutorial

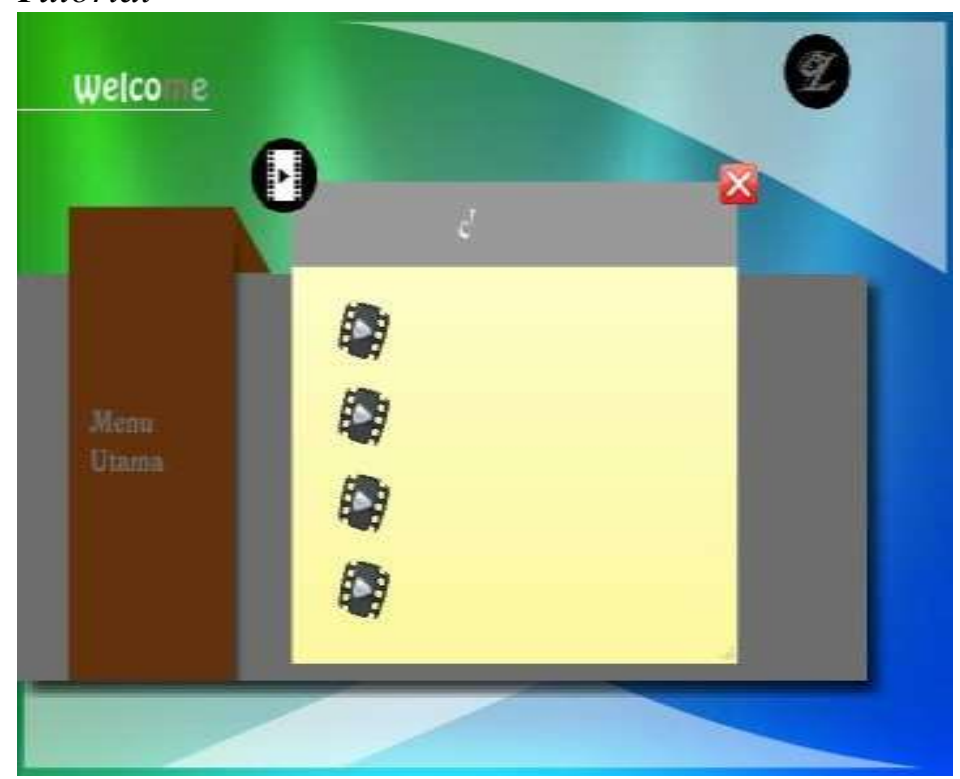

Tampilan halaman Video Tutorial

Dalam Halaman Video Tutorial siswa dapat melihat video tutorial dari materi yang sedang dipelajari di LKP Citra Sarana Bahasa dan Informatika (CSBI).

\section{Kesimpulan}

1. Komputer merupakan satu perangkat pengolah data yang dapat didesain dan dikembangkan untuk membantu manusia menjalankan aktivitasnya

2. Sebagai alternatif sumber belajar, komputer digunakan untuk mentransfer materimateri kepada peserta didik atau dalam konteks pembelajaran disebut dengan Media Pembelajaran Berbasis Komputer.

3. Media pembelajaran adalah semua bentuk perantara yang digunakan dalam pembelajaran yang berupa informasi, pendapat atau gagasan yang dapat memberi rangsangan kepada peserta didik sehingga terjadi interaksi antara pemberi pesan dan penerima pesan.

4. Komputer adalah seperangkat elektronik yang dapat menerima masukan (input), dan selanjutnya melakukan pengolahan (process) untuk menghasilkan keluaran (output) berupa informasi secara cepat melalui suatu program atau aplikasi tertentu.

5. Bentuk-bentuk penggunaan komputer sebagai media pembelajaran : Penggunaan Multimedia Presentasi, CD Multimedia Interaktif, dan Video Pembelajaran

6. Kelebihan komputer sebagai media pembelajaran : Menciptakan iklim belajar yang efektif bagi siswa yang lambat (slow learner), memacu efektivitas belajar bagi siswa yang cepat (fast learner), komputer dapat diprogram untuk memeriksa dan memberikan skor hasil belajar secara otomatis, dapat dijadikan sebagai sarana untuk pembelajaran yang bersifat individual (individual learning), komputer mampu 
mengintegrasi warna, musik dan animasi grafik, dapat meningkatkan hasil belajar dengan penggunaan waktu dan biaya yang relatif kecil.

7. Kelemahan komputer sebagai media pembelajaran : Tingginya biaya pengadaan dan pengembangan program komputer, terutama yang dirancang khusus untuk maksud pembelajaran, pemeliharaan dan perawatan komputer yang meliputi memerlukan biaya yang relatif tinggi, perangkat lunak sebuah komputer seringkali tidak dapat digunakan pada komputer yang spesifikasinya tidak sama.

\section{Daftar pustaka}

[1] Djamarah, Syaiful B dan Zain, Aswan.(2002) Strategi Belajar mengajar. Jakarta. Rineka Cipta.

[2] Heinich, R., et. al. (1996)Instructional Media and Technologies for Learning. New Jersey: Prentice Hall, Englewood Cliffs.

[3] Hamalik, Oemar (1986). Media Pendidikan. Bandung. Alumni.

[4] Oetomo, B.S.D. dan Priyogutomo, Jarot. Kajian Terhadap Model e-Media dalam Pengembangan Sisstem e-Education, Makalah Seminar Nasional Informaika 2004 di Universitas Ahmad Dahlan Yogyakarta pada 21 Pebruari 2004.

[5] Kustandi dan Sutjipto (2011). Media Pembelajaran Manual dan Digital.Bogor, Ghalia Indonesia.

[6] Nana Sujana dan Ahmad Riva'i. (1989). Teknologi Pengajaran, Bandung: Sinar Barn.

[6] Yusufhadi Miarso (2004). Menyemai Benih Teknologi Pendidikan.Jakarta. Kencana Media Group.

[7] Utomo, Junaedi, 2001. Dampak Internet Terhadap pendidikan: Transparansi dan Evolusi, Seminar Nasional Universitas Atma Jaya Yogyakarta, 7 April 2001. 